\title{
INCONGRUENCE IN BRAND NAMES AND ITS EFFECT ON CONSUMER PREFERENCE
}

\section{NEPODUDARNOST U NAZIVIMA MARKE I NJEZIN UTJECAJ NA PREFERENCIJU POTROŠAČA}

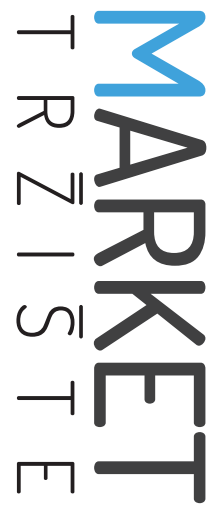

\author{
Market-Tržište \\ Vol. 31, No. 1, 2019, pp. 83-96 \\ UDK 658.89:658.626(594) \\ DOl http://dx.doi.org/10.22598/mt/2019.31.1.83 \\ Preliminary communication
}

\begin{abstract}
Ferdian Hendrasto ${ }^{a}$, Bagus Ibnu Utama ${ }^{b}$
a Universitas Gajayana, Faculty of Economics and Business, Jl. Mertojoyo Blok L, Merjosari - Malang, Jawa Timur, INDONESIA, e-mail: ferdian.h@unigamalang.ac.id

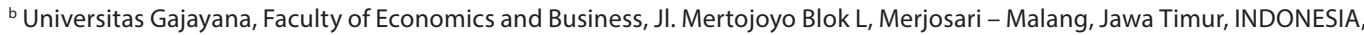
e-mail: bagusibnuutama@unigamalang.ac.id
\end{abstract}

\begin{abstract}
Purpose - Brand name is one of the determining factors of a brand's success. Simple brand names capable of capturing consumers' attention will make them easy to remember and get to perceive the brand. The significance of brand names has caused practitioners to have high consideration in determining brand names for products. With the sprouting up of new SME-based businesses in Indonesia, it is worth studying how these new businesses name their products. Specifically, we aim to analyze how different brand name designs affect consumer preference.
\end{abstract}

Design/Methodology/Approach - This study employed a $3 \times 2$ experimental method where respondents were exposed to three types of fictional brand names that were congruent (e.g., Coffee Corner), incongruent (e.g., d'Coffee Corner) and highly incongruent (e.g., d'Koffee Korner), the respondents' evaluation was observed through their preference against 3 types of brand name congruence and the use of Indonesian and English in the brands. The analysis technique utilized was a two-way ANOVA.

Findings and Implications - The results indicated that congruent brand names had the highest effect on consumer preference in comparison to incongruent and

\section{Sažetak}

Svrha - Naziv marke jedan je od odlučujućih čimbenika njezina uspjeha. Jednostavni nazivi koji mogu privući pažnju potrošača omogućuju im lako pamćenje i percipiranje marke. Važnost naziva dovela je do toga da praktičari obraćaju veliku pozornost određivanju naziva marke za proizvode. S rastom novih malih i srednjih poduzeća u Indoneziji, važno je proučiti kako ona dodjeljuju nazive svojim proizvodima. Konkretnije, cilj je analizirati kako različito oblikovanje naziva marke utječe na preferenciju potrošača.

Metodološki pristup - Istraživanje primjenjuje $3 \times 2$ eksperimentalnu metodu u kojoj su ispitanici izloženi trima vrstama izmišljenih naziva marke; podudarajućem (npr. Coffee Corner), nepodudarajućem (npr. d'Coffee Corner), te izrazito nepodudarajućem (npr. d'Koffee Korner). Procjena je provedena kroz njihove preferencije $u$ odnosu na tri vrste podudarnosti naziva marke te uporabu indonezijskog i engleskog jezika u markama. Za analizu je korištena dvosmjerna ANOVA.

Rezultati i implikacije - Rezultati su pokazali da su podudarajući u usporedbi s nepodudarajućim i vrlo nepodudarajućim nazivima marke imali najveći utjecaj na preferenciju potrošača. Međutim uporaba indonezijskog i engleskog jezika u markama nije pokazala značajnu razliku u potrošačkim preferencijama. 
highly incongruent brand names. The use of Indonesian and English in the brand names, however, showed no significant difference on consumer preference.

Limitation - The main limitation of this study consists in localized research samples and objects. Consequently, the result may not be the same in a wider, more general environment.

Originality - This research study contributes to the examination of brand designs by applying the theory of incongruence as a foundation for the analysis. It adds to the existing knowledge by investigating consumer preference on differently designed, new brand names.

Keywords - brand name, brand equity, theory of incongruence, consumer preference, brand preference
Ograničenja - Glavno ograničenje rada je vezano uz lokalni uzorak i objekte istraživanja. Posljedično, rezultat možda ne bi bio isti u širem, općenitijem okruženju.

Doprinos - Istraživanje doprinosi prethodnim istraživanjima o oblikovanju marke primjenjujući teoriju nepodudarnosti kao temelj za njegovu analizu. Nadograđuje se na postojeća znanja istražujući preferencije potrošača o različito oblikovanim, novim nazivima marke.

Ključne riječi - naziv marke, tržišna vrijednost marke, teorija nepodudarnosti, preferencije potrošača, preferencije marke 


\section{INTRODUCTION}

Brand names are one of the determining factors of a brand's success. Brand names are often simple but capable of capturing the attention of consumers so that they would easily remember and get to know the brand (Kotler \& Keller, 2016). The more consumers know a brand, the better the product can be distinguished from other, similar products. Through easily recognized brand names, companies gain added value for their products which, in turn, results in positive brand equity from their consumers' perspective (Aaker, 1991; Keller \& Sood, 2003).

The significance of brand names has caused practitioners to be cautious in determining brand names of a product. Brand names should not be formulated without sound consideration. This is so because brand equity depends on brand value, where brand value arises from a brand name itself (Leuthesser, Kohli \& Harich, 1995).

In Indonesia, the issues concerning brand names are noteworthy because now there are more start-ups growing in Indonesia on micro, as well as small and medium scales. Quoting from the data published by the Indonesian Central Bureau of Statistics (Badan Pusat Statistik, 2016), the number of small and medium enterprises (SME) in Indonesia grew at a relatively significant pace from 39,765,110 SME business units in 1997 to $50,145,800$ business units in 2007. This trend continued, so the figure for the number of SMEs in Indonesia in 2013 reached 57,895,721. Thus, in the span of 16 years, from 1997 to 2013, the number of SMEs in Indonesia increased by $45.6 \%$. In terms of employment, SMEs also recorded a relatively positive increase. In 1997, they employed 65,601,591 workers in Indonesia but by 2013 this number jumped to 114,144,082 workers. In other words, employment absorption by SMEs in 2013 increased by $73.9 \%$ compared to that in 1997. The Ministry of Cooperatives and Small and Medium Enterprises also noted that the contribution of the micro, small and medium enterprise sector to the gross domestic product (GDP) advanced from 57.84\% to
$60.34 \%$ over the course of five years (Ministry of Industry of the Republic of Indonesia, 2016).

Based on these data, it is evident that SMEs are one of the cornerstones of the Indonesian economy. With the rapid growth of new SME-based businesses in Indonesia, it is worth learning how these new businesses name their products. As previously explained, brand name is one of the factors forming brand equity where a company with an excellent brand equity will be capable of easily generating income (Ailawadi, Lehmann \& Neslin, 2003; Rao \& Monroe, 1989).

As one of the growing cities in Indonesia, Malang City also experiences an increase in the growth of SMEs. One phenomenon arising from the emergence of these businesses is the naming of businesses or brands which tend to be unique. Many business brands in Malang City are named using a combination of English and Indonesian or even adopting English with intentionally mistaken pronunciation, often resulting in unusual brand names. In fact, intentionally incorrect spelling of brand names is not a new phenomenon. Some well-known global brands have adopted this strategy, which has proven successful. For example, Google is taken from English word googol, meaning the number 1 with 100 zeros, while Kool-Aid intentionally alters the letter " $c$ " in cool with a " $k$ ". Toys-Я-Us contracts the word "are" into a single letter " $R$ ", which is then flipped vertically into " $A$ ". Some other brand examples include Flickr, in which the letter " $e$ " is eliminated from the word flicker; conversely, Digg adds an extra letter " $g$ " to the core word "dig". Such intentionally misspelled brand naming actually has its advantages because, by employing this strategy, the company obtains a catchy brand name that distinguishes it from other brands. Hence, companies always attempt to name the brands differently but not too extremely in a bid to provoke a sense of curiosity among their consumers and ultimately make the brand name more prominent in the consumers' mind (Keller \& Sood, 2003).

In Malang City, the trend of intentionally misspelled brand naming may be narrowed down

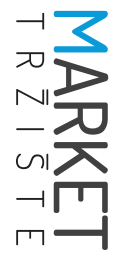




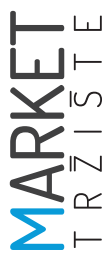

into two patterns. The first is writing the English word "the" using a " $d$ "' or "de", whereas the second involves combining this element " $\mathrm{d}$ " or "de" with the main word of the brand in both Indonesian and English. In contrast to the global phenomenon, brand naming in Malang City is intentionally mistaken and tends to follow certain trends of distinguishing brand names that have no valid basis.

In the field of psychology, a theory related to this phenomenon is referred to as the theory of incongruence; it claims that a slight difference will cause people to become curious and, in turn, trigger their involvement in the incongruence (Morreall, 2012). The difference will increase the appeal of the brand to consumers, so they will crave for more information and process it. Nevertheless, when the incongruence is highly extreme or has no obvious basis, consumers will not be able to process the information about the brand (Swaminathan, Gürhan-Canli, Kubat \& Hayran, 2015).

The aforementioned reviews have spurred the authors' interest in studying this phenomenon on consumer preferences when they are correlated to congruent and incongruent brand names, both in Indonesian and English. This research study aimed to determine how effective misspelled brand naming is in the context of using foreign-looking " $\mathrm{d}$ "' and "de" to replace "the" in a selection of Indonesian and English brand names in order to attract consumer attention.

\section{THEORETICAL ANALYSIS AND HYPOTHESES}

There are several previous studies examining incongruence in various brand-naming contexts. The research conducted by Melnyk, Klein and Volckner (2012) tested the use of foreign languages for the naming of several brands from both developed and developing countries. These brand names in foreign languages referred to certain countries, so the brand names were expected to trigger the association of high quality of these brands. The phenomenon observed included an increase in the use of foreign-language brand names; thus, consumers often face foreign names typical of a particular country's language while the brand itself is not even produced in that country. This research study tested such incongruent information in the country of origin (COO) through four experiments; research results indicated that the incongruence in hedonic products had a negative effect on consumer purchase decisions, while in utilitarian products the effect was insignificant.

Other research conducted by Meyers-Levy, Louie and Curren (1994) examined the theory of incongruence in the naming of certain product brands. In their research, the respondents evaluated new products named in an incongruent, not highly congruent, and highly incongruent manner. The results suggested that the products named in a not highly congruent manner were more favorable than those named in a congruent and highly incongruent manner. Thus, the theory of incongruence, claiming that a less overly striking difference will cause people to be curious and inquisitive about the differences, confirmed $t$.

Brand names are among very valuable assets of a company. Therefore, the decision concerning the naming of a brand usually goes through a thorough process of consideration relating it to the company's goals (Keller \& Lehman, 2006). A brand name, as a tangible asset of a company, is the aspect evaluated first by consumers (Strielkowski, Platt \& Wang, 2013). Logically, consumers will positively evaluate congruent brand names rather than incongruent ones. Congruent here means that brand names are used in accordance with the prevailing grammar, without any intentional misspelling or writing errors. This notion was confirmed by some previous research studies, in which consumers evaluated congruent brand names as being more favorable than when they were exposed to products with incongruent brand names (Rao \& Monroe, 1989; Grewal, Krishnan, Baker \& Borin, 1998). However, the theory of incongruence and several other studies supporting it confirm that incongruence, at a certain level where it is not overly significant, will be capable of making consumers 
favor the brands more (Deci \& Ryan, 1985; Hunt, 1965; Meyers-Levy et al., 1994).

According to the theory of incongruence, differences that are not overly significant will increase attraction; thus, people will be more willing to receive and process information from the incongruence. However, when the incongruence is extreme, that is, when the difference is so significant that it prevents certain messages from being communicated, consumers will find it difficult to understand them, and the information intended to be delivered by the company is rejected. A difference intentionally made only to be different without any strong foundation for it will only compromise the brand instead of giving it benefits because consumers perceive the difference to be uninteresting (Swaminathan et al., 2015).

Incongruence in this research study refers to the intentional misspelling of brand names. In this research context, an intentional error in brand naming refers to a substitution of the word "the" with " $\mathrm{d}^{\prime \prime}$ or "de", then combining it with the core word of the brand, using either Indonesian or English. The core word of the brand, in addition to being written in proper Indonesian and English, can also be written using intentionally misspelled English (for example, koffee instead of coffee). The respondents were exposed to three types of brand naming, namely, congruent (Coffee Corner), incongruent (d'Coffee Corner) and highly incongruent (d'Koffee Korner), which were expected to result in different consumer preferences. Based on the theory of in- congruence, a slight insignificant difference will make consumers favor the brand more. Therefore, the following hypotheses were formulated:

H1. Consumers prefer incongruent brand names to congruent and highly incongruent brand names.

H2. Consumers prefer Indonesian brand names to English brand names.

H3. The incongruence combined with brand names intentionally misspelled in either English or Indonesian will reduce consumer preference in comparison to the incongruence combined with brand names in properly spelled English and Indonesian.

\section{RESEARCH METHOD}

This study used a $3 \times 2$ between-subjects factorial design-experiment in brand names design as follows: brand name congruence, consisting of 3 (three) congruence categories, i.e. congruent brand name, incongruent brand name, and highly incongruent brand name. In addition, the language choice between Indonesian and English was employed in brand names. The factorial design was selected based on an experimental design, where the interaction effects between variables can be observed properly (Anshori \& Iswati, 2009). This study employed fictitious brand name logos to avoid the possibility of bias due to familiarity with already available advertisements. The factorial design of this research can be seen in Table 1 .

TABLE 1: Factorial research design

\begin{tabular}{|c|c|c|c|c|}
\hline & \multicolumn{3}{|c|}{ Language incongruence levels } \\
\hline & & Congruent & Incongruent & Highly incongruent \\
\hline \multirow{2}{*}{$\begin{array}{l}\text { Brand } \\
\text { language } \\
\text { choice }\end{array}$} & Indonesian & $\begin{array}{l}\text { Brand name with } \\
\text { proper grammar } \\
\text { and spelling } \\
\text { written in standard } \\
\text { Indonesian }\end{array}$ & $\begin{array}{l}\text { Brand names with } \\
\text { improper grammar } \\
\text { and spelling } \\
\text { written in standard } \\
\text { Indonesian }\end{array}$ & $\begin{array}{l}\text { Brand names with } \\
\text { improper grammar and } \\
\text { spelling written in non- } \\
\text { standard Indonesian }\end{array}$ \\
\hline & English & $\begin{array}{l}\text { Brand name with } \\
\text { proper grammar } \\
\text { and spelling written } \\
\text { in standard English }\end{array}$ & $\begin{array}{l}\text { Brand names with } \\
\text { improper grammar } \\
\text { and spelling written } \\
\text { in standard English }\end{array}$ & $\begin{array}{l}\text { Brand names with } \\
\text { improper grammar and } \\
\text { spelling written in non- } \\
\text { standard English }\end{array}$ \\
\hline
\end{tabular}

Source: Development of research experimental models, 2018 
Technically, the population in this study covered all college students who had the experience of visiting a café in Malang City. The sample of college students in Malang City was selected because they tend to share a similar mindset and behavior; thus, they were expected to provide a relevant contribution to this study. The number of respondents employed in this study refers to the standards of Roscoe (1975) and Hair, Black, Babin, Anderson and Tatham (2010), namely, 30 respondents for each group examined. Therefore, there were 6 groups in this study, with the total sample consisting of 180 respondents.

The respondents were selected using the non-probability purposive sampling technique. After being determined, the respondents were placed in random groups. This random placement was conducted by giving sequential numbers to research subjects, starting from numbers 1-6. This technique was adapted to avoid bias which can affect the internal validity of this study.

This random placement technique also ensures that the variables measured were indeed those measured in this study. This technique enables controlling the strength of extra variables by ensuring that any differences occurring in the results of the respondents' answers were influenced by manipulation variables, instead of the extra variables (Batara-Goa, 2015). The main part of this research was carried out by assigning 6 types of different treatment of brand names through 6 different brand names. The brand names were distinguished by the incongruence in language use (congruent, incongruent, and highly incongruent) and the language choice used in the brand (Indonesian and English). These 6 combinations were then analyzed for their effects on consumer preferences. The consumer preferences in this research were measured using 3 items as developed by Overby and Lee (2006) and Dhar (1997), namely:

1. I like this café logo.

2. Looking at this logo makes me interested in this café.

3. I intend to visit this café.
The data collected in this study were analyzed using a two-way ANOVA technique, which was chosen because the study applied two independent variables acting as a treatment, namely the level of language incongruence (X1) and brand language (X2). The initial step of data analysis involved testing the validity and reliability of the measurement instruments. The validity testing was conducted by employing the Pearson correlation test, where if the score is less than 0.05, the data is declared valid (Ghozali, 2011). Meanwhile, the reliability test was conducted by looking at the value of Cronbach's alpha. If the value of Cronbach's alpha reaches 0.7, the data is declared to be reliable (Hair et al., 2010). Next, the data undergoes the normality test to find out whether the respondents' answers are normally distributed.

After the validity, reliability and normality tests are carried out, the collected data are eligible to undergo a two-way ANOVA hypothesis test. This analysis technique is utilized to test the effect of both manipulation variables against a measured variable, that is, the consumer preference. The two-way ANOVA result is determined based on the significance value: if the significance value is below the cut-off value of 0.05, the proposed hypothesis is accepted. If the proposed hypothesis is accepted, a post hoc test will be carried out to identify whether the groups have different mean value. This is done by employing a Tukey post hoc test because the output generated is easy to interpret and capable of describing the groups with significant mean value differences (Burns, Bush \& Sinha, 2014).

\section{ANALYSIS AND DISCUSSION}

Both the manipulation test and core research survey utilized a single set of fictitious brand logos as the instrument. First, these brand logos were shown to the respondents, who were then asked to fill out a questionnaire. The brand logos used can be seen in Figure 1 . 
FIGURE 1: Brand logos used in research

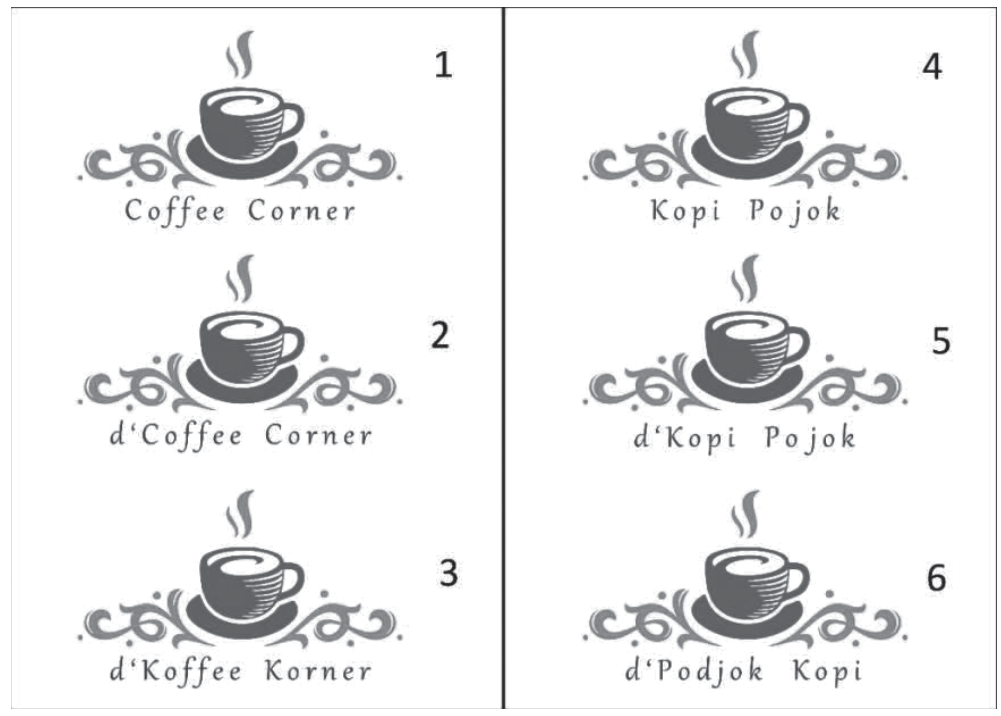

Source: Researcher design, 2018

Logo number 1 is a brand logo in English with congruent grammar, number 2 represents the brand logo in English with incongruent grammar, and number 3 represents the brand logo in English with highly incongruent grammar. In the neighboring column, logo number 4 is a brand logo in Indonesian with congruent grammar, number 5 represents the brand logo in Indonesian with incongruent grammar, with number 6 representing the brand logo in Indonesian with highly incongruent grammar.

The manipulation test was conducted to find out whether the manipulation done in this study was completely different. Brand Language Choice Manipulation, namely Indonesian and English, was not required because the researchers assumed that the difference between English and Indonesian could be clearly differentiated by the respondents. The manipulation test examined the congruence level of the utilized language, depending on whether the language used in the brand logo was congruent, incongruent, or highly incongruent. A total of 30 respondents participated in this manipulation test.
The manipulation test results of logo number 1 indicated that all respondents (100\%) categorized it as a brand logo with congruent grammar. Meanwhile, 25 of 30 respondents (83\%) categorized number 2 as a brand logo with incongruent grammar. As to the last brand logo in English, namely number 3, 23 of 30 respondents (76\%) categorized it as a brand logo with highly incongruent grammar.

Among the brand logos in Indonesian on the right in Figure 1, similarly to the English counterparts, all respondents (100\%) categorized logo number 4 as a brand logo with congruent grammar, with 23 out of 30 respondents (76\%) categorizing number 5 as a brand logo with incongruent grammar, while number 6 was categorized by 22 out of 30 respondents (73\%) as a brand logo with highly incongruent grammar.

Based on the manipulation test results, the researchers concluded that the six brand logo images used in this research could be well distinguished by the respondents, as evident in the percentage of respondents categorizing each image of the brand logo of no less than $60 \%$. 
Therefore, the research could proceed by using the aforementioned brand logos.

Using the purposive sampling method, the researchers and the team assisting them distributed questionnaires to 180 respondents in several strategic places in Malang City. The respondents in this study were college students, both men and women, of whom most had visited cafés at least once in the previous month.

In an experimental method, it is crucial for researchers to attain a balanced composition of respondent number to avoid bias and to increase the generalization of research results (Burns et al., 2014). Based on gender, this research sample was composed of nearly balanced numbers of female and male respondents: 82 out of 180 respondents (45\%) were male, while the remaining 98 respondents (55\%) were female.

They were divided into 3 categories by the frequency of their visits to cafés in the previous month: 47 of 180 respondents (26\%) said they had visited a café at least once over the past month. Another 64 of 180 respondents (36\%) said they visited cafés between 2 and 3 times in the previous month. Lastly, 69 out of 180 respondents (9\%) claimed that they visited cafés more than 3 times in the past month.

The respondents' descriptive statistics for the dependent variable of the research, namely the Consumer Preference $(Y)$, were evaluated to determine the extent to which consumers like or dislike the logos employed in this research. The results are provided in Table 2.
The following analysis can be made based on Table 2:

1. The results of the descriptive statistics for Y1 (congruent Indonesian) had an average value of 4.22 , which indicated that the consumer preference against brand logos in Indonesian with congruent grammar was good. The standard deviation value reached 0.702 , indicating a variation in consumer preference against brand logos in congruent Indonesian of $16.63 \%$ in comparison to the average value.

2. The results of the descriptive statistics for Y2 (incongruent Indonesian) had an average value of 3.51, which indicated that the consumer preference against brand logos in Indonesian with incongruent grammar was fairly good. The standard deviation value reached 0.552 , indicating a variation in consumer preference against brand logos in incongruent Indonesian of $15.67 \%$ in comparison to the average value.

3. The results of the descriptive statistics for $Y 3$ (highly incongruent Indonesian) had an average value of 2.19, indicating that the consumer preference against brand logos in Indonesian with highly incongruent grammar was bad. The standard deviation value of 0.653 indicated a variation in consumer preference against brand logo in highly incongruent Indonesian of $29.68 \%$ in comparison to the average value.

4. The results of the descriptive statistics for Y4 (congruent English) had an average value of 4.41, indicating that the consumer

\section{TABLE 2: Descriptive statistics}

\begin{tabular}{|c|c|c|}
\hline Variable & Mean & Standard deviation \\
\hline Y1 (Congruent in Indonesian) & 4.22 & 0.702 \\
\hline Y2 (Incongruent in Indonesian) & 3.51 & 0.552 \\
\hline Y3 (Highly incongruent in Indonesian) & 2.19 & 0.653 \\
\hline Y4 (Congruent in English) & 4.41 & 0.347 \\
\hline Y5 (Incongruent in English) & 3.29 & 0.583 \\
\hline Y6 (Highly incongruent in English) & 1.87 & 0.423 \\
\hline
\end{tabular}

Source: Processing of descriptive statistical data, 2018 
preference against brand logo in English with congruent grammar was good. The standard deviation value of 0.347 indicated a variation in consumer preference against brand logos with congruent English of $7.87 \%$ in comparison to the average value.

5. The results of the descriptive statistics for $Y_{5}$ (incongruent Indonesian) have an average value of 3.29, which indicates that consumer preference against brand logo in English with incongruent grammar was fairly good. The standard deviation had a value of 0.583 , indicating a variation in consumer preference against brand logos with incongruent English of $17.72 \%$ in comparison to the average value.

6. The results of the descriptive statistics for $Y 6$ (highly incongruent English) have an average value of 1.87, indicating that the consumer preference against brand logo in English with highly incongruent grammar was bad. The standard deviation value of 0.423 indicated a variation in consumer preference against brand logos with highly incongruent English of $22.62 \%$ in comparison to the average value.

The next step was to test the validity and reliability of the questionnaire. The validity testing was done using the Pearson correlation test, where the criteria for achieving validity were the significance values of less than 0.05 (Ghozali, 2011). Meanwhile, the reliability test was taken by looking at the value of Cronbach's alpha, where the value of Cronbach's alpha was more than 0.7, indicating that the questionnaire was reliable. A summary of results of validity and reliability testing is provided in Table 3.
It can be concluded from Table 3 that all the items were valid and reliable because they had significance values below 0.05 and Cronbach's alpha values higher than 0.7. After the questionnaire was declared valid and reliable, the distribution of research data was investigated using the Kolmogorov-Smirnov normality test. Its results can be seen in Table 4.

\section{TABLE 4: Normality test}

\begin{tabular}{|l|c|}
\cline { 2 - 2 } \multicolumn{1}{c|}{} & $\begin{array}{c}\text { Consumer } \\
\text { preferences }\end{array}$ \\
\hline $\mathrm{N}$ & 180 \\
\hline Kolmogorov-Smirnov Z & 1.469 \\
\hline Asymp. Sig. (2-tailed) & 0.027 \\
\hline
\end{tabular}

Source: Results of data processing, 2018

It is evident that the dependent variable was found not to be normally distributed because it had a significance value of less than 0.05 . However, data not normally distributed would not affect the results of the study, because of the number of respondents used totaled 180 and was included as a large sample group (BataraGoa, 2015). Referring to the central limit theorem, if a research uses a large number of respondents ( $n>30$ ), the data will come closer to the normal distribution even though the sample is not normally distributed (Rice, 2003). The research conducted by Schmider, Ziegler, Danay, Beyer, and Buhner (2010) also provides empirical evidence that data not normally distributed can still be used in the ANOVA test.

TABLE 3: Validity and reliability tests

\begin{tabular}{|l|l|c|c|}
\hline \multicolumn{2}{|c|}{ Y_item1 } & Pearson correlation & 0.909 \\
\cline { 2 - 3 } & Sig. (2-tailed) & 0.000 \\
\hline \multirow{2}{*}{ Y_item2 } & Pearson correlation & 0.918 \\
\cline { 2 - 3 } & Sig. (2-tailed) & 0.000 \\
\hline \multirow{2}{*}{ Y_item3 } & Pearson correlation & 0.925 \\
\cline { 2 - 3 } & Sig. (2-tailed) & 0.000 & \\
\hline
\end{tabular}

Source: Data processing, 2018 
The hypothesis testing was completed by utilizing a two-way ANOVA test, followed by post hoc test. The results of the two-way ANOVA testing can be seen in Table 5 . difference in each level of congruence - be it between congruent and non-congruent, congruent and highly incongruent, or incongruent and highly incongruent - was significant.

TABLE 5: Two-way ANOVA test results

\begin{tabular}{|c|l|c|c|c|}
\hline Dependent variable & \multicolumn{1}{|c|}{ Interaction } & Mean square & F & Sig. \\
\hline \multirow{3}{*}{ Consumer preferences } & Incongruence & 79.290 & 255.122 & .000 \\
\cline { 2 - 5 } & Language choice & .560 & 1802 & .181 \\
\cline { 2 - 5 } & Incongruence x language choice & 1.052 & 3.385 & .036 \\
\hline
\end{tabular}

Source: Results of data processing, 2018

From table 5, it can be seen that the incongruence had a significance value of less than 0.05 . This means that the language incongruence level (X1) had a significant influence on consumer preferences $(Y)$. Meanwhile, the interaction between language and consumer preference, with a significance level of less than 0.05 , means that language choice (X2) had no significant influence on consumer preferences $(Y)$. The interaction between incongruence and language choice simultaneously indicated a significance value of under 0.05 , meaning that the incongruence level combined with language choice significantly influenced consumer preferences (Y). The post hoc test was carried out because the incongruence level exerted significant influence on consumer preferences, with the summary of its results provided in Table 6.

The post hoc test found all interactions at the language congruence level to have a significance value of under 0.05 . This means that the
The first hypothesis suggested that consumers would prefer incongruent brand names to congruent or highly incongruent brand names. From the results of the ANOVA test, it was evident that the interaction between language congruence level and brand preference had a significance value of 0.000 or less than 0.05 . This means that the language incongruence level significantly influenced consumer preference, resulting in average language incongruence values for the congruent, incongruent and highly incongruent categories of brand names of 4.22, 3.51, and 2.19 respectively for Indonesian, and 4.41, 3.29, and 1.87 respectively for English.

The average values suggested that the consumer preference for the logos using incongruent language was lower than for those with congruent language, or 4.22 vs. 3.51 for Indonesian and 4.41 vs. 3.29 for English. Nonetheless, the consumer preference for logos with incongruent language was higher than for highly incon-

TABLE 6: Post hoc test

\begin{tabular}{|l|l|c|c|c|}
\hline \multicolumn{2}{|c|}{ (I) Incongruence } & Mean difference (IJ) & Std. Error & Sig. \\
\hline \multirow{2}{*}{ Congruent } & Incongruent & 0.9113 & 0.10178 & 0.000 \\
\cline { 2 - 5 } & Severely incongruent & 2.2837 & 0.10178 & 0.000 \\
\hline \multirow{2}{*}{ Incongruent } & Congruent & -0.9113 & 0.10178 & 0.000 \\
\cline { 2 - 5 } & Incongruent & 1.3723 & 0.10178 & 0.000 \\
\hline \multirow{2}{*}{ Highly incongruent } & Congruent & -2.2837 & 0.10178 & 0.000 \\
\cline { 2 - 5 } & Incongruent & -1.3723 & 0.10178 & 0.000 \\
\hline
\end{tabular}

Source: Results of data processing, 2018 
gruent language, namely, 3.51 vs. 2.19 for Indonesian, and 3.29 vs. 1.87 for English. Therefore, the first hypothesis was accepted.

The language choice between English and Indonesian, which is part of the second hypothesis, constitutes an interesting point to analyze as it resulted in no differences in brand preferences between the respondents presented with logos in Indonesian and English. This is evident from the significance value of 0.181 , which was more than 0.05. Therefore, the second hypothesis was rejected.

The third hypothesis stated that incongruence combined with intentionally misspelled brand names in English and Indonesian would reduce consumer preference compared to that in a combination with correct English and Indonesian brand names. The results of the ANOVA test showed the interaction of incongruence level and language choice to have a significance value of 0.036 or less than 0.05 . This means that incongruence combined with the language choice of brands significantly influenced consumer preference.

Incongruence combined with proper English and Indonesian (d'Coffee Corner and d'Kopi Pojok) with the score of 3.51 and 3.29, respectively, has a higher mean rate than incongruence combined with improper English and Indonesian (d'Koffee Korner and d'Podjok Kopi) at 2.19 and 1.87 , respectively. Therefore, the third hypothesis was accepted.

Business entities have a variety of assets to support their operations. Brand name is a fairly valuable asset for companies. Brand name is not only decided through a robust decision-making process but must also have a meaning and be in accordance with the company's goals (Keller \& Lehman, 2006). The results of this research found brand names written according to correct spelling and grammar rules to have the highest effect in influencing consumer preference; this was in contract to brand names intentionally misspelled, both using the correct grammar (incongruent) or wrong grammar (highly incon- gruent). These results support the outcome of research conducted by Rao and Monroe (1989) and Grewal and others (1998), stating that consumers will favor congruent brands more than incongruent ones. On the other hand, this study contradicts the results of research by Deci and Ryan (1985), Hunt (1965), and Meyers-Levy and others (1994), finding that incongruence on a certain level tends to make consumers love certain brands.

The research results, however, contradict the theory of incongruence, which states that insignificant differences would increase attraction. Nonetheless, that does not necessarily mean that the research results can replace the theory of incongruence. The researchers' use of intentionally misspelled brand names in this study was not based on a strong basis or strategy, and merely followed a trend which was not based on the philosophy of the brand itself. Therefore, it confirmed that consumers do not consider intentional misspelling in brand names to be an interesting point (Swaminathan et al., 2015).

At the most basic level, this research provided an explanation regarding the correlation between the use of a certain language system and type and consumers' preference. The explanation in this research was based on incongruence theory. The authors hypothesized and found that consumers would prefer to interact with brands that had congruent grammar than those with incongruent or highly incongruent grammar. However, they did not delve into the brand names designed in either local language or in English. What proved interesting from our research results was the fact that they contradicted the incongruence theory. The research conducted by Priester, Godek, Nayankuppum and Park (2004) indicated that comparative advertisements produced greater elaboration. Instead of comparison that produced elaboration, it was the incongruence of an advertisement element that produced greater elaboration. The research conducted by Meyers-Levy and others (1994) also suggested a similar notion, where brands with a moderate level of incongruence

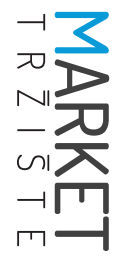


were preferred by the consumers to those that were congruent and highly congruent. Contrary to the aforementioned research results, this research did not find that incongruence would improve elaboration. In fact, brands with congruent grammar, both Indonesian and English, had the highest effect on consumers' preference. In their study, Priester and others (2004) stated that greater elaboration occurred because individuals as consumers were capable of thinking and enjoyed it. Therefore, comparative advertisement that contained incongruent brand names were preferred by the consumers, because the incongruence drove people to think. We argued that such a phenomenon of the use of " $d$ " and " $d$ " as substitutes for "the" as our research objects, despite being an example of the application of the incongruence theory, was not capable of improving the elaboration and consumers' preference. This was so because such a phenomenon of grammar use that occurred on the research location was highly common, resulting in having no clear meaning or purpose. It indicated that consumers, as individuals who were capable of and keen on thinking would, in fact, not be interested because of numerous similar brands using deliberately mistaken English grammar.

Such common use of deliberately mistaken English grammar in the city where our research took place stripped the brands of unique characteristics. In fact, brand characteristics that can be concluded from the brand names are a crucial matter. Brands with clear and unique characteristics would attract consumer attention with those congruent characteristics (Sung \& Choi, 2010). Indeed, a brand with a strong image could draw consumer attention. Robertson (1989) explained some factors that must come into consideration when designing a great brand name. Among them was that the brand name should not only be different but could also be easily associated with the product's class. In addition, that brand name must also trigger a mental image. The research results suggested that the brand names that were intriguingly designed massively failed to create a difference and did not even succeed in raising consumers' preference. In other words, based on the results of our research, incongruence has morphed into congruence.

The use of English and Indonesian in a brand to attract the attention of consumers was found not to yield any significant difference. This means that, in this era of globalization, English has become a global language used not only in formal events but also in everyday life (Northrup, 2013).

This research study has several limitations. First, this study employed a specific research location, i.e., Malang City, Indonesia, even though the use of misspelled brand names is common to many other cities and other countries as well. Therefore, nationwide research could be conducted so that research results can be more generalized. Second, this study examined brand names merely against consumer preference. In view of the fact that many factors, such as brand equity and image (Cobb-Walgren, Ruble \& Donthu, 1995), price, physical appearance, and company reputation (Rao \& Monroe, 1989; Dawar \& Parker, 1994), can affect consumer preference, researchers keen on developing this research further could add the aforementioned variables as the factors influencing consumer preference.

Another line of investigation into brand names and brand logos might also consider conducting experiments that would including their additional treatment, such as the logo color as an element that can also influence consumer preferences (Madden, Hewett \& Roth, 2000).

\section{CONCLUSION AND SUGGESTIONS}

Based on the research results on the theory of incongruence and its influence on consumer preference, it can be concluded that:

1. Correct spelling and grammar in brand names could increase consumer preference, compared to intentional misspelling and ungrammatical writing. This proves 
that the determination of brand names must be aligned with company goals and, as much as possible, apply no intentional misspelling or ungrammatical writing.

2. The use of Indonesian and English in brands does not cause any difference in consumer preference. It implies that business people, especially in Indonesia, can safely choose brand names both in Indonesian and English, in accordance with their company goals.

For practitioners, the results of this study indicate that brand naming in Indonesia, should not be based solely on the trends emerging in the surrounding area. Brand names must be determined through a solid decision-making process, so that they are a manifestation of the company's goals. Brand name alone, even without advertisement support, could influence sales (Kohli \& Labahn, 1997). Thus, the company must remember that its consumers are capable of thinking in a cognitive manner. Designing brand names by following the trends in the market is similar to assuming that consumers are incapable of telling good brand names from bad ones. If a company wants to design a distinct brand name, it is noteworthy to remember the philosophy behind the distinctiveness itself. There are many examples of brand names deliberately made differently, yet which preserved the meaning behind their uniqueness (e.g., the already mentioned Google brand name, as an adaptation of the English word "googol", KoolAid that intentionally replaces the correct initial in "cool" with the letter "k", Toys-Я-Us that gives the impression it has been written by a child, etc.). Companies can learn from such brand naming; with good brand names, companies can expect to be positively accepted by consumers in the market, and that in turn will influence the success of the product itself.

\section{References}

1. Aaker, D. A. (1991). Managing Brand Equity. New York, NY: The Free Press.

2. Ailawadi, K. L., Lehmann, D. R., \& Neslin, S. A. (2003). Revenue Premium as an Outcome Measure of Brand Equity. Journal of Marketing, 67(4), 1-17.

3. Anshori, M., \& Iswati, S. (2009). Metodologi Penelitian Kuantitatif. Surabaya: Pusat Penerbitan dan Percetakan UNAIR.

4. Badan Pusat Statistik (2016). Tabel Perkembangan UMKM pada Periode 1997-2013. Retrieved from: $\quad$ https://www.bps.go.id/statictable/2014/01/30/1322/tabel-perkembangan-umkm-pada-periode-1997--2013.html.

5. Batara-Goa, A. B. (2015). Penggunaan Goal Framing Hope Appeal, Executional Framework dan Endorser pada Iklan Layanan Masyarakat. Master thesis. Jawa Timur: Universitas Airlangga.

6. Burns, A. C., Bush, R. F., \& Sinha, N. (2014). Marketing research. Harlow: Pearson.

7. Cobb-Walgren, C. J., Ruble, C. A., \& Donthu, N. (1995). Brand equity, brand preference, and purchase intent. Journal of advertising, 24(3), 25-40.

8. Dawar, N., \& Parker, P. (1994). Marketing Universals: Consumers' Use of Brand Name, Price, Physical Appearance, and Retailer Reputation as Signals of Product Quality. Journal of Marketing, 58(2), 81-95.

9. Deci, E., \& Ryan, R. M. (1985). Intrinsic Motivation and Self-determination in Human Behavior. Berlin: Springer Science \& Business Media.

10. Dhar, R. (1997). Consumer Preference for a No-choice Option. Journal of Consumer Research, 24(2), 215-231.

11. Ghozali, I. (2011). Aplikasi Analisis Multivariate dengan Menggunakan Program IBM SPSS19. Semarang: Universitas Diponegoro. 
12. Grewal, D., Krishnan, R., Baker, J., \& Borin, N. (1998). The effect of store name, brand name and price discounts on consumers' evaluations and purchase intentions. Journal of Retailing, 74(3), 331-352.

13. Hair, J. F., Black, W. C., Babin, B. J., Anderson, R. E., \& Tatham, R. L. (2010). Multivariate Data Analysis. Ney York, NY: Pearson Prentice Hall.

14. Hunt, J. (1965). Intrinsic Motivation and its Role in Psychological Development. Nebraska Symposium on Motivation (Vol. 13, pp. 189-282). University of Nebraska Press.

15. Keller, K. L., \& Lehmann, D. R. (2006). Brands and Branding: Research Findings and Future Priorities. Marketing Science, 25(6), 740-759.

16. Keller, K. L., \& Sood, S. (2003). Brand Equity Dilution. MIT Sloan Management Review, 45(1), 12.

17. Kohli, C., \& LaBahn, D. W. (1997). Creating effective brand names: A study of the naming process. Journal of advertising research, 37(1), 67-75.

18. Kotler, P., \& Keller, K. L. (2016). Marketing Management. Boston, MA: Pearson.

19. Leuthesser, L., Kohli, C. S., \& Harich, K. R. (1995). Brand Equity: The Halo Effect Measure. European Journal of Marketing, 29(4), 57-66.

20. Madden, T. J., Hewett, K., \& Roth, M. S. (2000). Managing Images in Different Cultures: A Cross-National Study of Color Meanings and Preferences. Journal of International Marketing, 8(4), 90-107.

21. Melnyk, V., Klein, K., \& Völckner, F. (2012). The Double-Edged Sword of Foreign Brand Names for Companies from Emerging Countries. Journal of Marketing, 76(6), 21-37.

22. Meyers-Levy, J., Louie, T. A., \& Curren, M. T. (1994). How Does the Congruity of Brand Names Affect Evaluations of Brand Name Extensions?. Journal of Applied Psychology, 79(1), 46-53.

23. Morreall, J. (2012). Philosophy of Humor.

24. Northrup, D. (2013). How English Became the Global Language. London: Palgrave Macmillan.

25. Overby, J. W., \& Lee, E. J. (2006). The Effects of Utilitarian and Hedonic Online Shopping Value on Consumer Preference and Intentions. Journal of Business Research, 59(10/11), 1160-1166.

26. Priester, J. R., Godek, J., Nayakankuppum, D. J., \& Park, K. (2004). Brand Congruity and Comparative Advertising: When and Why Comparative Advertisements Lead to Greater Elaboration. Journal of Consumer Psychology, 14(1/2), 115-123.

27. Rao, A. R., \& Monroe, K. B. (1989). The Effect of Price, Brand Name, and Store Name on Buyers' Perceptions of Product Quality: An Integrative Review. Journal of Marketing Research, 26(3), 351-357.

28. Rice, J. A. (2003). Mathematical Statistics and Data Analysis. Beijing: China Machine Press.

29. Robertson, K. (1989). Strategically Desirable Brand Name Characteristics. Journal of Consumer Marketing, 6(4), 61-71.

30. Roscoe, J. T. (1975). Fundamental Research Statistics for the Behavioural Sciences. $2^{\text {nd }}$ ed. New York, NY: Holt Rinehart and Winston.

31. Schmider, E., Ziegler, M., Danay, E., Beyer, L., \& Bühner, M. (2010). Is It Really Robust? Reinvestigating the Robustness of ANOVA against Violations of the Normal Distribution Assumption. Methodology, 6(4), 147-151.

32. Strielkowski, W., Platt, S., \& Wang, J., (2013). Consumer Preferences for Cultural Heritage and Tourism E-services: A Case Study of Three European Cities. Market-Tržište, 25(2), 161-176.

33. Sung, Y., \& Choi, S. M. (2012). The Influence of Self-Construal on Self-Brand Congruity in the United States and Korea. Journal of Cross-Cultural Psychology, 43(1), 151-166.

34. Swaminathan, V., Gürhan-Canli, Z., Kubat, U., \& Hayran, C. (2015). How, When, and Why Do Attribute-Complementary Versus Attribute-Similar Cobrands Affect Brand Evaluations: A Concept Combination Perspective. Journal of Consumer Research, 42(1), 45-58. 